\title{
Virology, DNA Viruses, General
}

National Cancer Institute

\section{Source}

National Cancer Institute. Virology, DNA Viruses, General. NCI Thesaurus. Code C19115.

The study of DNA viruses. 